\title{
Aspects of Epstein-Barr virus infection in childhood
}

\author{
R. N. P. SUTTON, S. D. MARSTON, E. J. P. ALMOND, and R. T. D. EMOND \\ From the Department of Medical Microbiology, King's College Hospital Medical School; and the Royal Free \\ Hospital Infectious Diseases Unit, Coppetts Wood Hospital, London
}

\begin{abstract}
Sutton, R. N. P., Marston, S. D., Almond, E. J. P., and Emond, R. T. D. (1974). Archives of Disease in Childhood, 49, 102. Aspects of Epstein-Barr virus infection in childhood. Antibodies to Epstein-Barr (EB) virus capsid antigen and EB virus complement fixing antibodies were estimated in sera from 23 children and 27 young adults with infectious mononucleosis, and in 79 control patients. Complement fixing antibodies, but not those to virus capsid antigen, were much lower in patients tested during acute infectious mononucleosis than in controls. It is suggested that this disparity could form the basis of a diagnostic test. Anomalous results, in which the $\mathrm{EB}$ virus antibody pattern suggested active infection though heterophile antibodies and/or abnormal white blood cells were absent, were observed in sera from patients of all ages but the majority were aged 5 years or less. The proportion of sera with EB virus antibodies increased throughout childhood, suggesting that infection with this virus is relatively frequent in this age group and may often be unrecognized.
\end{abstract}

The association between infection with EB virus and infectious mononucleosis is now well established (Niederman et al., 1970; Sawyer et al., 1971; University Health Physicians and Public Health Laboratory Service, 1971). Many infections with this virus must nevertheless be asymptomatic and, while antibodies appear to be acquired throughout childhood (Henle, Henle, and Diehl, 1968; Pereira, Blake, and Macrae, 1969), the peak incidence of clinical infectious mononucleosis is in early adult life (Hobson, Lawson, and Wigfield, 1958; Niederman, 1956; Newell, 1957). There has been speculation (Evans, 1960) that infectious mononucleosis might occur in unrecognized forms during childhood, and certainly the diagnosis of this condition in children of 5 years of age and under is often difficult (Carter and Penman, 1969). We have observed that in active infectious mononucleosis complement fixing antibodies to a soluble antigen present in cultured Burkitt tumour cells develop much later than antibodies to the EB virus capsid antigen (Sutton $e t$ al., 1971a). This disparity, for which there is no satisfactory explanation at present, could be used as a basis for a diagnostic test. In this report we describe the results of such tests in children with infectious mononucleosis and with other conditions.

Materials and methods

Sera were obtained from children admitted to hospitals for infectious diseases and to children's hospitals.

Received 26 July 1973.
Infectious mononucleosis was diagnosed in some, the criteria for diagnosis being clinical, together with a positive heterophile antibody test and the presence of typical abnormal cells in the peripheral blood. Other children had a variety of conditions. In some it was clearly not infectious mononucleosis (e.g. patients with typhoid fever or with congenital heart disease), and in others there was some doubt that was often unresolved after a full range of investigations. In this report we consider these children solely from the point of view of possible EB virus infection. For further comparison, a group of young adults (aged 18 to 21 years) admitted to a hospital for infectious diseases with definite infectious mononucleosis and with other conditions was also included.

Serological methods. The EB3 cell line was used as a source of antigen. This line had been obtained from Professor M. A. Epstein in 1968 and was subsequently cultured in a medium consisting of Eagle's MEM (78\%), fetal calf serum $(20 \%), 200 \mathrm{mmol} / 1$. glutamine $(1 \%)$, and non-essential amino acids (1\%) with added penicillin and streptomycin. The cells were grown in $250 \mathrm{ml}$ flasks, 50 $\mathrm{ml}$ of cell suspension to each flask, and were incubated at $37^{\circ} \mathrm{C}$. An antigen was prepared by adjusting the cell count to $2 \times 10^{7}$ cells $/ \mathrm{ml}$ and disrupting the cells by four cycles of freezing and thawing, the antigen then being clarified by slow centrifugation. The micromethod of Takátsy (1955), as adapted and modified by Sever et al. (1964), was used in complement fixation tests. Assay of antibodies to the EB virus capsid antigen was carried out by the method of Henle and Henle (1966), slightly modified in that the microscope slides were treated with a polytetrafluorethylene aerosol to give 14 clear spaces, 
each about $3 \mathrm{~mm}$ in diameter, in which the EB3 cell smears were spread.

In both types of test sera were coded and examined in ignorance of the diagnosis, and certain techniques were always carried out by the same operator. Test and control sera were examined together in the same experiments in batches of about 16 to 25 . As the numbers were small and as the subjects were children, the results for both sexes were pooled for analysis. The $\chi^{2}$ test with Yates's correction or, in the case of small numbers, Fisher's exact test (Bailey, 1959) were used in tests of statistical significance.

\section{Results}

EB virus antibodies in young adults. Antibodies to EB virus capsid (VCA) and to EB soluble complement fixing (CF) antigens were estimated in sera from 27 young adults, aged 18 to 21 years, with confirmed infectious mononucleosis and in sera from 24 control individuals of the same ages with other conditions (mostly infectious diseases). All sera were obtained within 30 days of the onset of illness. The prevalence of antibodies to virus capsid antigen was virtually the same in both groups, but significant differences were found in the levels of complement fixing antibodies (Table I). A pattern of antibodies (VCA antibodies with low levels of CF antibodies) was apparent which was significantly associated with infectious mononucleosis and was much less frequently observed in the control patients.

Of 7 patients with infectious mononucleosis, 6 who were tested 6 months to 2 years later developed $\mathrm{CF}$ antibodies to $\mathrm{EB}$ virus at levels of $1 / 16$ or over $(P=0.0023$, Fisher's exact test). Thus, in this age group an EB CF antibody level greater than $1 / 16$ may reasonably be interpreted as evidence of a previous EB virus infection.

EB virus antibodies in children. Complement fixing antibodies to EB virus were estimated in
TABLE I

$E B$ virus capsid antigen (VCA) and complement fixing $(C F)$ antibodies in young adults with infectious mononucleosis and other conditions

\begin{tabular}{|c|c|c|c|}
\hline $\begin{array}{l}\text { EB virus } \\
\text { antibodies }\end{array}$ & $\begin{array}{l}\text { Infectious } \\
\text { mononucleosis }\end{array}$ & $\begin{array}{l}\text { Other } \\
\text { conditions }\end{array}$ & $\begin{array}{c}\text { Significance of } \\
\text { differences }\end{array}$ \\
\hline $\begin{array}{l}\text { VCA antibody at } \\
\text { level } \geqslant 1 / 8 \\
C F \text { antibody at } \\
\text { level } \leqslant 1 / 16 \\
\text { VCA antibody at } \\
\text { level } \geqslant 1 / 8+ \\
\text { CF antibody at } \\
\text { level } \leqslant 1 / 16\end{array}$ & $\begin{array}{c}16 / 27 \star \\
(j 9 \%) \\
2 j / 30 \\
(83 \%) \\
\\
12 / 27 \\
(44 \%)\end{array}$ & $\begin{array}{c}15 / 24^{\star} \\
(62 \%) \\
9 / 26 \\
(35 \%) \\
\\
3 / 24 \\
(12 \cdot 5 \%)\end{array}$ & $\begin{array}{l}\chi_{2}=0.003 \\
P<0.95(\mathrm{NS}) \\
\chi^{2}=10.1 \\
P<0.001\end{array}$ \\
\hline
\end{tabular}

^Denominator signifies number of subjects tested. NS, not significant.

sera from 141 children with conditions other than infectious mononucleosis or leukaemia; antibodies to EB virus capsid antigen were estimated in $\mathbf{5 2}$ of these. The proportion with detectable antibodies rose with age (Table II). EB CF antibody levels of greater than 1/16 suggest past infection and the proportion with such antibodies rose from $18 \%$ at $<6$ months of age to $65 \%$ at 18 to 21 years.

There were 23 patients, aged 15 years or less (mean age 10.7 years, 5 aged 5 years or less), with infectious mononucleosis who were tested for both CF and VCA antibodies. 22 had one or both antibodies, as did 33 of 54 patients (mean age 7.04 years, 22 aged 5 years or less) with other conditions $(P=0.0012$, Fisher's exact test). $10(43 \%)$ of these 23 patients with infectious mononucleosis had the pattern of antibodies associated in adults with infectious mononucleosis (Table III). 9 of 54 children with other conditions also had this pattern; 5 of these were aged 5 years or less.

In Table IV are the clinical features in these 9 children and 3 young adults with the serological

TABLE II

Antibodies to $E B$ virus in control children

\begin{tabular}{|c|c|c|c|c|c|}
\hline Age groups & $<6 \mathrm{mth}$ & $6 \mathrm{mth}-5 \mathrm{yr}$ & $6-10 \mathrm{yr}$ & $11-15 \mathrm{yr}$ & $18-21 \mathrm{yr}$ \\
\hline $\begin{array}{l}\text { EB complement fixing antibody } \\
\text { No. tested } \\
\text { Antibody level } \geqslant 1 / 4 \\
\text { Antibody level }>1 / 16\end{array}$ & $\begin{array}{c}27 \\
20 \\
(74 \%) \\
5 \\
(18 \%)\end{array}$ & $\begin{array}{c}42 \\
29 \\
(69 \%) \\
13 \\
(31 \%)\end{array}$ & $\begin{array}{c}36 \\
27 \\
(75 \%) \\
16 \\
(44 \%)\end{array}$ & $\begin{array}{c}36 \\
29 \\
(81 \%) \\
19 \\
(53 \%)\end{array}$ & $\begin{array}{c}26 \\
24 \\
(92 \%) \\
17 \\
(65 \%)\end{array}$ \\
\hline Age groups & $<6 \mathrm{mth}$ & $6 \mathrm{mth}-5 \mathrm{yr}$ & \multicolumn{2}{|c|}{$6-15 \mathrm{yr}$} & $18-21 \mathrm{yr}$ \\
\hline $\begin{array}{l}E B \text { virus capsid antigen } \\
\text { antibody } \\
\text { No. tested } \\
\text { Antibody level } \geqslant 1 / 8\end{array}$ & $\frac{\text { Nil }}{-}$ & $\begin{array}{c}20 \\
8 \\
(40 \%)\end{array}$ & & & $\begin{array}{c}24 \\
9 \\
(63 \%)\end{array}$ \\
\hline
\end{tabular}


TABLE III

$E B$ virus capsid antigen (VCA) and complement fixing $(C F)$ antibodies in patients with infectious mononucleosis and with other conditions

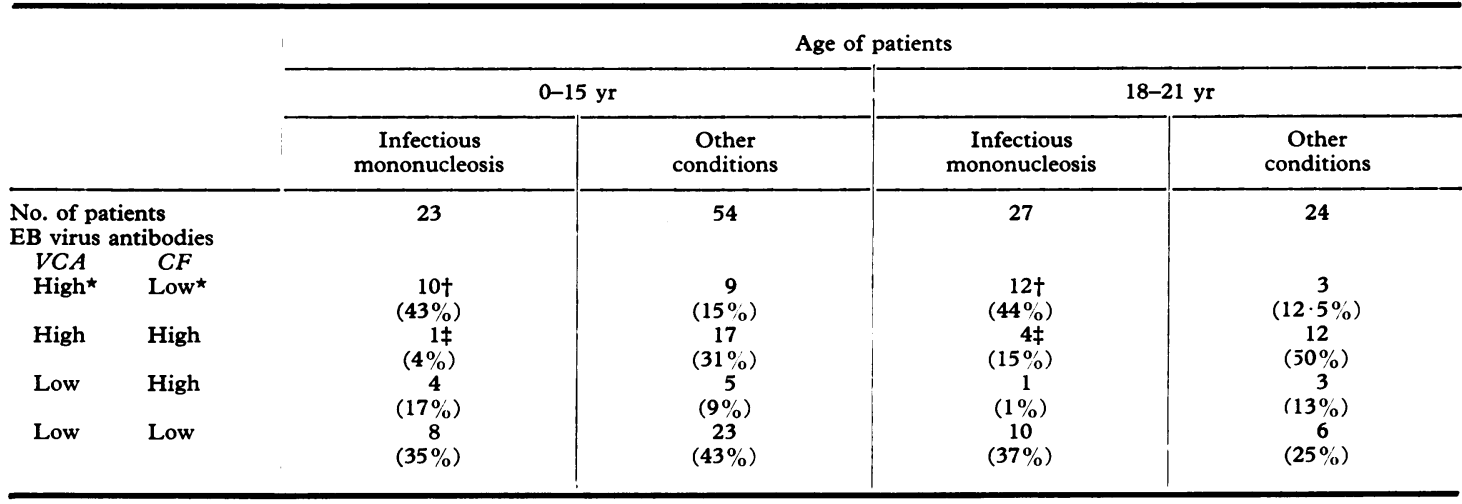

$\star$ High VCA antibodies $=$ levels $\geqslant 1 / 8$; low CF antibodies $=$ levels $\leqslant 1 / 16$.

Significance of differences between patients with infectious mononucleosis and other conditions: $† P<0.02 ; \ddagger P<0.01$.

pattern associated with infectious mononucleosis, but in whom this diagnosis could not be supported (usually because of the lack of heterophile antibody). The majority of these patients had upper respiratory tract infections, sometimes associated with a rash, or were diagnosed as infective hepatitis.

\section{Discussion}

Although the detection of heterophile antibodies, together with the observation of typical abnormal cells in the peripheral blood, are mainstays in the diagnosis of infectious mononucleosis, recognition that the EB virus is the probable causative agent has extended the field of investigation into this disease. The clinical features in childhood form one of the more puzzling aspects (Carter and Penman, 1969), and standard serological tests in this group are often unhelpful, especially in children aged under 5 years (Vahlquist, Ekelund, and Tveteras, 1958). In this situation the detection of recent EB virus infection would be valuable. Unfortunately, neither the recovery of the virus in susceptible cells achieved by

TABLE IV

Clinical features of control patients with antibody patterns suggesting recent EB virus infection

\begin{tabular}{|c|c|c|c|c|c|c|c|}
\hline \multirow{2}{*}{$\begin{array}{l}\text { Case no. and } \\
\text { age }\end{array}$} & \multicolumn{2}{|c|}{ EB virus antibodies } & \multirow{2}{*}{ Sex } & \multirow{2}{*}{ Age (yr) } & \multirow{2}{*}{$\begin{array}{l}\text { Heterophile } \\
\text { antibody }\end{array}$} & \multirow{2}{*}{ Abnormal WBC } & \multirow{2}{*}{ Clinical features } \\
\hline & CF & VCA & & & & & \\
\hline$<5 \boldsymbol{y r}$ & & & & & & & \\
\hline 1 & $1 / 4$ & $1 / 32$ & $\mathbf{M}$ & $3 \mathrm{mth}$ & - & - & Gastroenteritis \\
\hline 2 & $<1 / 4$ & $1 / 16$ & $\mathbf{M}$ & $2 \mathrm{mth}$ & - & - & $\begin{array}{l}\text { Bronchitis with hepatomegaly } \\
\text { and rash }\end{array}$ \\
\hline 3 & $1 / 16$ & $1 / 64$ & $\mathbf{M}$ & 1 & - & + & Tonsillitis + splenomegaly \\
\hline 4 & $1 / 4$ & $1 / 32$ & $\mathbf{M}$ & 1 & - & - & $\begin{array}{l}\text { Respiratory infection + rash + } \\
\text { convulsion }\end{array}$ \\
\hline 5 & $1 / 8$ & $1 / 8$ & $\mathbf{M}$ & 3 & $\mathbf{w k}+$ & - & $\begin{array}{l}\text { Upper respiratory tract } \\
\text { infection + rash }\end{array}$ \\
\hline $6-10 y r$ & & & & & & & \\
\hline 6 & $1 / 8$ & $1 / 64$ & $\mathbf{M}$ & 8 & ND & ND & $\begin{array}{l}\text { Pigmented rash ?post-measles } \\
\text { (measles CF antibody } 1 / 1024 \text { ) }\end{array}$ \\
\hline${ }_{11-15}^{7} y r$ & $1 / 16$ & $1 / 32$ & $\mathbf{M}$ & 7 & - & + & Infective hepatitis \\
\hline 8 & $1 / 16$ & $1 / 16$ & $\mathbf{M}$ & 11 & - & + & $\begin{array}{l}\text { Pyrexia of unknown origin }+ \\
\text { lymphadenopathy }\end{array}$ \\
\hline$\stackrel{9}{18-21} y r$ & $1 / 8$ & $1 / 16$ & $\mathbf{F}$ & 11 & ND & ND & Healthy child \\
\hline $\begin{array}{l}10 \\
11 \\
12\end{array}$ & $\begin{array}{l}1 / 16 \\
1 / 4 \\
1 / 8\end{array}$ & $\begin{array}{l}1 / 128 \\
1 / 128 \\
1 / 64\end{array}$ & $\begin{array}{l}\mathbf{F} \\
\mathbf{F} \\
\mathbf{F}\end{array}$ & $\begin{array}{l}18 \\
18 \\
19\end{array}$ & $\begin{array}{l}- \\
-\end{array}$ & $\begin{array}{l}- \\
+\end{array}$ & $\begin{array}{l}\text { Infective hepatitis } \\
\text { Tonsillitis } \\
\text { Tonsillitis }\end{array}$ \\
\hline
\end{tabular}

ND, not done. 
several groups of workers (Pereira et al., 1972; Gerber et al., 1972; Chang and Golden, 1971; Miller, Niederman, and Andrews, 1973) nor the detection of specific EB virus IgM antibody (indicating recent infection) described by Banatvala, Best, and Waller (1972) are procedures which can readily be applied on a large scale. The disparity which we have observed between the rates of development of EB complement fixing and virus capsid antigen antibodies (Sutton et al., 1971; Sutton et al., 1973) therefore becomes of some practical use.

The proportions of children at different ages with antibodies suggested that possibly 30 to $40 \%$ of children in our selected group had been infected with $\mathrm{EB}$ virus by their fifth year and that infection thereafter occurred throughout childhood at a rate of perhaps $2 \%$ a year. Some infections were clearly apparent as infectious mononucleosis and the EB virus antibody pattern in these children closely resembled that seen in a control group of young adults. Anomalous results, where the EB virus studies suggested recent infection though there was no serological evidence for infectious mononucleosis, were frequent in those aged 5 or under, an age group where positive Paul-Bunnell-Davidsohn reactions are almost unknown (Vahlquist et al., 1958). In these patients with anomalous results, the clinical picture in most cases comprised features commonly associated with infectious mononucleosis (tonsillitis, abnormal peripheral leucocytes, hepatitis). It seems reasonable to classify these patients as suffering from atypical infectious mononucleosis rather than some other condition, and the estimation of $\mathrm{EB}$ virus antibodies may be useful in confirming the diagnosis.

We do not know how many children experience subclinical infections with EB virus. In our series one apparently healthy child showed evidence of recent asymptomatic infection. Such asymptomatic infections are not uncommon in young adults (Sutton et al., 1974). In childhood the rate of acquisition of EB virus antibodies far exceeds the incidence of infectious mononucleosis and we must assume that the majority of infections pass unrecognized. Such infections may be quite innocuous, but we may legitimately question this assumption for in young adults there is good evidence that antibodies to smooth muscle develop during such subclinical infections (Sutton et al., 1974) and the relation of such antibodies to liver damage and to malignant disease are now well recognized (Ajdukiewicz et al., 1972; Whitehouse and Holborow, 1971; Johnson, Holborow, and Glynn, 1965).
We are grateful to Drs. Hillas Smith, D. I. K. Evans, H. R. Gamsu, A. P. Mowat, and Professor C. E. Stroud for help in this investigation; and to Professor J. A. Dudgeon and the consultant staff of The Hospital for Sick Children, Great Ormond Street, for sending serum specimens for investigation. Financial support was provided by the Medical Committee, King's College Hospital, the Leukaemia Research Fund, and the Cancer Research Campaign.

\section{REFERENCES}

Ajdukiewicz, A. B., Dudley, F. J., Fox, R. A., Doniach, D., and Sherlock, S. (1972). Immunological studies in an epidemic of infective, short-incubation hepatitis. Lancet, 1, 833.

Bailey, N. T. J. (1959). Statistical Methods in Biology, p. 61. English Universities Press, London.

Banatvala, J. E., Best, J. M., and Waller, D. K. (1972). EpsteinBarr virus-specific IgM in infectious mononucleosis, Burkitt lymphoma and nasopharyngeal carcinoma. Lancet, 1, 1205.

Carter, R. L., and Penman, H. G. (1969). Infectious Mononucleosis, pp. 32, 215. Blackwell Scientific Publications, Oxford and Edinburgh.

Chang, R. S., and Golden, H. D. (1971). Transformation of human leucocytes by throat washing from infectious mononucleosis patients. Nature, 234, 359.

Evans, A. S. (1960). Infectious mononucleosis in University of Wisconsin students. American fournal of Hygiene, 71, 342.

Gerber, P., Nonoyama, M., Lucas, S., Perlin, E., and Goldstein, L. I. (1972). Oral excretion of Epstein-Barr virus by healthy subjects and patients with infectious mononucleosis. Lancet, 2, 988.

Henle, G., and Henle, W. (1966). Immunofluorescence in cells derived from Burkitt's lymphoma. Fournal of Bacteriology, 91, 1248.

Henle, G., Henle, W., and Diehl, V. (1968). Relation of Burkitt's tumor-associated herpes-type virus to infectious mononucleosis. Proceedings of the National Acadamy of Sciences of the United States of America, 59, 94.

Hobson, F. G., Lawson, B., and Wigfield, M. (1958). Glandular fever: a field study. British Medical fournal, 1, 845.

Johnson, G. D., Holborow, E. J., and Glynn, L. E. (1965). Antibody to smooth muscle in patients with liver disease. Lancet, 2, 878.

Miller, G., Niederman, J. C., and Andrews, L. (1973). Prolonged oropharyngeal excretion of Epstein-Barr virus after infectious mononucleosis. New England fournal of Medicine, 288, 229.

Newell, K. W. (1957). The reported incidence of glandular fever, an analysis of a report of the Public Health Laboratory Service. fournal of Clinical Pathology, 10, 20.

Niederman, J. C. (1956). Infectious mononucleosis at the YaleNew Haven Medical Center, 1946-1955. Yale Fournal of Biology and Medicine, 28, 629.

Niederman, J. C., Evans, A. S., Subrahmanyan, L., and McCollum, R. W. (1970). Prevalence, incidence and persistence of EB virus antibody in young adults. New England fournal of Medicine, 282, 361.

Pereira, M. S., Blake, J. M., and Macrae, A. D. (1969). EB virus antibody at different ages. British Medical fournal, 4, 526.

Pereira, M. S., Field, A. M., Blake, J. M., Rodgers, F. G., Bailey, L. A., and Davies, J. R. (1972). Evidence for oral excretion of EB virus in infectious mononucleosis. Lancet, 1, 710.

Sawyer, R. N., Evans, A. S., Niederman, J. C., and McCollum, R. W. (1971). Prospective studies of a group of Yale University freshmen. I. Occurrence of infectious mononucleosis. Fournal of Infectious Diseases, 123, 263.

Sever, J. L., Ley, A. C., Wolman, F., Caplan, B. M., Pernell, M. T., Crockett, W., and Turner, H. C. (1964). Utilization of disposable plastic plates, with a serologic microtechnic. American fournal of Clinical Pathology, 41, 167.

Sutton, R. N. P., Almond, E. J. P., Marston, S. D., and Emond, R. T. D. (1971). Complement-fixing and fluorescent antibodies in diagnosis of EB virus infections. Lancet, 2, 1095.

Sutton, R. N. P., Marston, S. D., Almond, E. J. P., Reynolds, K., and Pounds, F. J. (1974). Asymptomatic infection with EB virus. Fournal of Clinical Pathology. (In the press.) 
Sutton, R. N. P., Reynolds, K., Almond, J. P., Marston, S. D., and Emond, R. T. D. (1973). Immunoglobulins and EB virus antibodies in infectious mononucleosis. Clinical and Experimental Immunology, 13, 359.

Takátsy, G. (1955). The use of spiral loops in serological and virological micro-methods. Acta Microbiologica Academiae Scientiarum Hungaricae, 3, 191.

University Health Physicians and Public Health Laboratory Service Laboratories Joint Investigations (1971). Infectious mononucleosis and its relationship to EB virus antibody. British Medical fournal, 4, 643.
Vahlquist, B., Ekelund, H., and Tveteras, E. (1958). Infectious mononucleosis and pseudo-mononucleosis in childhood. Acta Paediatrica, 47, 120.

Whitehouse, J. M. A., and Holborow, E. J. (1971). Smooth muscle antibody in malignant disease. British Medical fournal, 4, 511.

Correspondence to Dr. R. N. P. Sutton, Department of Medical Microbiology, King's College Hospital Medical School, Denmark Hill, London SE5 8RX. 